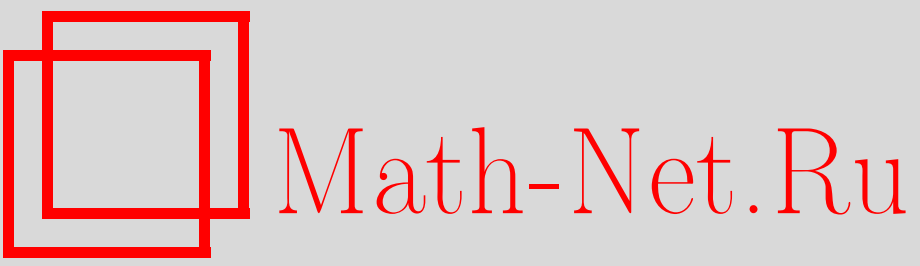

Д. В. Аносов, В. И. Арнольд, В. М. Бухштабер, В. А. Голубева, А. А. Гончар, А. Б. Жижченко, Ю. С. Ильяшенко, В. В. Козлов, С. П. Коновалов, Л. Д. Кудрявцев, В. П. Лексин, О. Б. Лупанов, А. А. Мальцев, Е. Ф. Мищенко, С. П. Новиков, Ю. С. Осипов, М. М. Постников, В. А. Садовничий, А. Г. Сергеев, Л. Д. Фаддеев, А. В. Чернавский, Андрей Андреевич Болибрух (некролог), УМH, 2003, том 58, выпуск 6, 139-142

DOI: https://doi.org/10.4213/rm677

Использование Общероссийского математического портала Math-Net.Ru подразумевает, что вы прочитали и согласны с пользовательским соглашением http://www . mathnet.ru/rus/agreement

Параметры загрузки:

IP: 54.237 .59 .107

26 апреля 2023 г., $17: 24: 09$ 


\section{АНДРЕЙ АНДРЕЕВИЧ БОЛИБРУХ}

11 ноября 2003 г. на 54-м году жизни скончался академик Андрей Андреевич Болибрух, заместитель директора МИАН, председатель секции математики ОМН РАН. Выдающийся математик, крупнейший специалист в области аналитической теории дифференциальных уравнений, он всегда стремился вперед, увлеченный своими новыми идеями. Ушел из жизни широко образованньй человек, служивший науке как своей научной деятельностью, так и огромной организационной работой.

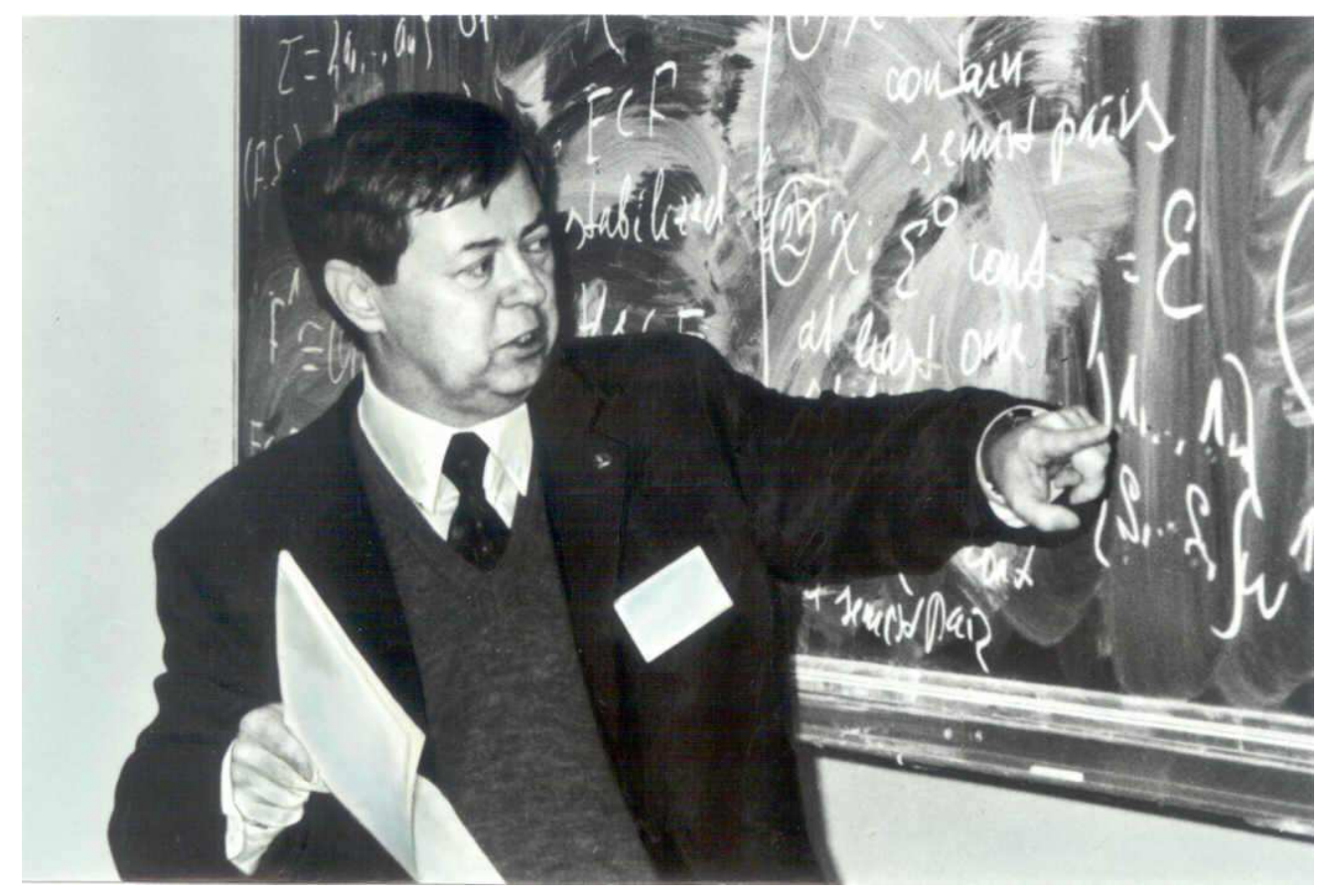

Андрей Андреевич Болибрух родился 30 января 1950 года в Москве в семье военнослужащего. Его отец, Андрей Власьевич Болибрух, был участником Великой Отечественной войны и продолжал службу в армии после нее, дойдя до звания генерал-лейтенанта и должности зам. командующего военным округом. Андрей Андреевич гордился своим отцом, особенно его героизмом в годы войны. Мама, Татьяна Ивановна, всецело посвятила себя воспитанию детей- Андрея и его сестры, тоже Татьяны. 
Военнослужащим нередко приходится часто менять место службы. Поэтому Андрей учился в различных школах. Последняя из них уже не была непосредственно связана с местом службы отца - это был интернат при ЛГУ. Выбор, видимо, до некоторой степени был связан с тем, что отец тогда служил в Прибалтике, к которой Ленинград ближе Москвы. Много лет спустя А.А. написал воспоминания о школе-интернате. Читая их, можно подумать, что они написаны если не профессиональным писателем, то представителем гуманитарной профессии.

В 1967-72 гг. Андрей Андреевич учился на механико-математическом факултете МГУ, затем в 1972-75 гг. - в аспирантуре того же факультета. В те годы его научным руководителем был М. М. Постников, и соответственно интересы А.А. были связаны с алгебраической топологией. Но, возможно, уже тогда у него формировалась и другая область интересов более аналитического характера. Известно, что некоторые аналитические вопросы (но не те, которые оказались в центре внимания А.А.) были не чужды и М. М. Постникову, хотя его известность связана не с ними. Окончательно область интересов А.А. определилась, когда с 1972 по 1997 г. он работал на кафедре высшей математики в Московском физико-техническом институте. Он попал туда при содействии тогдашнего заведующего кафедрой Л. Д. Кудрявцева, а на окончательное формирование его научных интересов большое влияние оказали А. В. Чернавский и В. А. Голубева. О той роли, которую эти три человека - Кудрявцев, Чернавский и Голубева сыграли в его жизни, А.А. всегда говорил с благодарностью.

В 1977 г. Андрей Андреевич защитил в МГУ кандидатскую диссертацию "О фундаментальной матрице пфаффовой системы фуксова типа". Это была уже аналитическая теории дифференциальных уравнений в многомерных комплексных областях.

Последующие 10 лет для А.А. были годами большого внутреннего роста, о котором едва ли знали даже его ближайшие друзья. В этот период он был отчасти связан с некоторыми прикладными работами, отчасти занимался пфаффовыми системами в комплексной области, существенно обогатив имеющуюся информацию о локальном поведении решений возле особенностей типа нормального пересечения. Это было определенным успехом, но слава ждала А.А. в, казалось бы, более простой теории систем линейных обыкновенных дифференциальных уравнений, где в конце 80-х гг. им была решена 21-я проблема Гильберта.

В проблеме речь идёт о построении системы линейных обыкновенных дифференциальных уравнений в комплексной области, грубо говоря, с предписанным характером ветвления решений в особых точках и со сравнительно умеренньм характером имеющихся в этих точках особенностей. В течение нескольких десятилетий считалось, что 21-я проблема Гильберта положительно решена Й. Племелем в начале ХХ в. Племель основьвался на сведении к некоторому другому своему результату. Последний совершенно правилен и, кстати, при его доказательстве Племель фактически заложил основы теории сингулярных интегральных уравнений, но что касается упомянутого сведения, то около 1980 г. несколько человек обнаружили, что это сведение не всегда работает. Однако справедливость доказьваемого утверждения всё ещё казалась правдоподобной, тем более что в паре специальных случаев, где рассуждения Племеля не работали, проходили другие доказательства. Поэтому, когда А.А. обнаружил, что при некотором выборе особых точек и характера ветвлений в них проблема может решаться отрицательно, это было неожиданным и блестящим достижением, составившим докторскую диссертацию А.А., защищенную в МИАН в 1991 г. Но это было только начало. Ситуация в данной области оказалась более сложной и разнообразной чем думалось ранее - открылся новый мир.

Дальнейшие работы Андрея Андреевича относились к этому миру, у которого он выявлял всё новые и новые свойства. Например, в последние годы А.А. уделял особое внимание точке зрения, связанной с векторными расслоениями, при этом ему помогло полученное в своё время топологическое образование.

С 1990 г. основным местом работы Андрея Андреевича стал МИАН. Несколько лет он продолжал еще преподавать на физтехе, но в 1996 г. стал профессором мехмата МГУ и вскоре оставил физтех. Достижения А.А. были признаны и оценены. В 1994 г. он был избран членом-корреспондентом РАН, в 1997 г. - академиком. В 1995 г. он был удостоен премии им. Ляпунова РАН, в 2001 г. - Государственной премии Российской Федерации, в 1999 г. стал почетным профессором МГУ, в 2003 г. - лауреатом гранта Благотворительного фонда содействия отечественной науке в области естественных и гуманитарных наук по номинации "Выдающиеся ученые" за 2003 г. 
Последний период жизни Болибруха показал новую грань таланта Андрея Андреевича - что он не только выдающийся ученьй, но и выдающийся организатор науки. С 1996 г. он был заместителем директора МИАН, затем, продолжая работать на этом посту, стал заместителем академика-секретаря ОМ РАН (позже ОМН РАН), председателем секции математики, вице-президентом ММО, членом Научного совета ИНТАС в 1996-99 гг., членом Научного совета Международного центра им. Банаха и попечительского совета МЦНМО. В 2002 г. он стал членом исполкома Международного союза математиков. Трудно переоценить его роль в организации научной работы в России и международного научного сотрудничества. В 1995-97 гг. он был приглашённым профессором в Университете Нищшы, в 1998-2002 гг. - приглашённым профессором Страсбургского университета. Он участвовал в работе многих международных конференций, часто будучи приглашённым пленарным докладчиком. Он всегда использовал встречи с иностранными коллегами для расширения международного сотрудничества не только в той области, в которой работал, но и в других областях математики.

У А.А., как и у всех, были интересы вне науки. У него это были литература, живопись, театр. Искреннее дружелюбие и артистичность помогали ему в личных контактах. Это трудно передать словами, но не случайно он приобрел много друзей во всем свете.

В последние полтора года А.А. проводил все больше и больше времени в больнице, но и там он продолжал работать: закончил последнюю научную работу, написал воспоминания, продолжал руководить как МИАНом, так и своими аспирантами.

Смерть Андрея Андреевича является не только трагедией для его родных и близких, но и большой потерей для математики и нашей страны.

Д. В. Аносов, В. И. Арнольд, В. М. Бухитабер, В. А. Голубева, А. А. Гончар, А. Б. Жижченко, Ю. С. Ильяшенко, В. В. Козлов, С. П. Коновалов, Л.Д. Кудрявчев, В. П. Лексин, О. Б. Лупанов, А. А. Мальцев, Е. Ф. Мищенко, С. П. Новиков, Ю.С. Осипов, М. М. Постников, В.А. Садовничий, А.Г. Сергеев, Л. Д. Фаддеев, А.В. Чернавский

\section{СПИСОК ИЗБРАННЫХ ТРУДОВ А. А. БОЛИБРУХА}

[1] Системы Пфаффо типа Фукса на комплексном аналитическом многообразии // Матем. сб. 1977. T. 103. № 1. C. 112-123

[2] О фундаментальной матрице системы Пфаффа типа Фукса // Изв. АН СССР. Сер. матем. 1977. T. 41. № 5. C. 1084-1109

[3] Проблема Римана-Гильберта на комп лексной проективной прямой // Матем. заметки. 1989. T. 46. № 3. C. $118-120$

[4] Проблема Римана-Гильберта // УМН. 1990. Т. 45. № 2. С. 3-47

[5] 21-я проблема Гильберта для линейных фуксовых систем. М.: Наука, 1994. (Труды МИАН. T. 206.)

[6] The Riemann-Hilbert Problem. Braunschweig: Vieweg, 1994. (Aspects Math. V. E22) (with D. V. Anosov)

[7] Фуксовы дифференциальные уравнения и голоморфные расслоения. М.: МЦНМО, 2000

[8] Об аналитическом преобразовании к стандартной биркгофовой форме // Докл. РАН. 1994. T. 334. № 5. C. 553-555

[9] Fuchsian systems with reducible monodromy and the Riemann-Hilbert problem // Lecture Notes in Math. 1992. V. 1520. P. 139-155

[10] The Riemann-Hilbert problem and Fuchsian differential equations on the Riemann sphere // Proceedings of the International Congress of Mathematicians (Zürich, 1994). Basel: Birkhäuser, 1995. P. 1159-1168

[11] On isomonodromic deformations of Fuchsian systems // J. Dynam. Control Systems. 1997. V. 3. № 4. P. 589-604

[12] Об изомонодромных слияниях фуксовых особенностей // Труды МИАН. 1998. Т. 221. C. $127-142$ 
[13] Levelt's valuation method and the Riemann-Hilbert problem // Differential and Difference Equations and Computer Algebra. In honor of A. H. M. Levelt's 65th birthday: University of Nijmegen, 1998. P. 1-9

[14] Стабильные векторные расслоения с логарифмическими связностями и проблема Римана-Гильберта // Докл. РАН. 2001. Т. 381. №1. С. 10-13

[15] On orders of movable poles of the Schlesinger equation // J. Dynam. Control Systems. 2000. V. 6. № 1. P. 57-73

[16] Неравенства Фукса на компактном кэлеровом многообразии // Докл. РАН. 2001. Т. 380. № 4. С. $448-451$

[17] Кратности нулей компонент решений системы с регулярньми особыми точками // Труды МИАН. 2002. Т. 236. С. 61-65

[18] Проблема Римана-Гильберта на компактной римановой поверхности // Труды МИАН. 2002. T. 238. C. $55-69$

[19] O tau-функции уравнения изомонодромных деформаций Шлезингера // Матем. заметки. 2003. T. 74. № 2. C. 184-191

[20] Обратные задачи монодромии аналитической теории дифференциальных уравнений // Математические события XX века. М.: Фазис, 2003. С. 53-79 